DOI: $10.21625 /$ archive.v2i2.249

\title{
Education and Tourism: The Inclusion of Ancestral Knowledge in the University Degree Curricula
}

\author{
Danny Rivera Flores ${ }^{1}$, Juan Carlos Pazán ${ }^{1}$, Corina Núñez ${ }^{1}$, Yolanda Pérez ${ }^{1}$ \\ ${ }^{1}$ Universidad Técnica de Ambato
}

\section{Keywords}

ancestral towns, interculturality, curricula, consmovision, integration

\begin{abstract}
Being able to recognize your own individual rights in vulnerable situations is a good way to live. A new curriculum developed under Ecuador's Higher Education Board brings together the inter-cultural concept. In ancient cultures, segregation existed among Latin American people in higher education. In this way, the new proposal for education makes it vital for future professionals to develop in the domain of methods and proceeds about ancient acknowledge, traditions, and cultural. To achieve the purpose of having inclusive curricula, it was needed to analyze ancient thoughts focused in the Salasaka community consmovision (descendant from Bolivia settled in Ecuador) and Chibuleos community who formulated the methodology that promotes cultural consciousness and is focused on the development and potentiation of habits and customs that generate different ways of living and thinking in the new educational environments. The obtained results are in function of statistics settings that show inclusive methodologies that link up the university professorship with ancient knowledge and culture. The use of this investigation is the implementation of methodologies in curricula in Ecuadorian universities in higher education. It's about transforming the ideological challenges on the academic formation of the ancestral towns.
\end{abstract}

\section{Introduction}

When we talk about knowledge, we make reference to the Socio-Constructivist Learning Theory. Ausubel (1968) establishes that there will only be significant learning when the content is relatable in a substantive and not arbitrary way with what the learner already knows, that is, with relevant and preexisting aspects of their cognitive structure (p13). It considers students as non-knowing beings, without light, but based on their previous knowledge of their school experiences and everyday life, they can build new and significant acquaintance and be the main actors of their own learning. Therefore, Robinson (1969) indicates that ancestral, traditional and popular knowledge, cognizance, and technologies will be integral axes of public management and will have an intercultural approach to their practices for the exercise of the plurinational state (p.5). This is similar to those who depend on the joint participation of possessing people's ancestral knowledge and succeed in eradicating discrimination and promoting equality, inclusion and gender equality.

Education constitutes an indispensable tool so that mankind can progress towards the ideals of peace, freedom and social justice. Hewitt Ramírez \& Barrero Rivera, (2011) state that its essential function is the development of people and societies as a means for human development that is more harmonic and genuine that allows for a decrease in poverty, exclusion, misunderstandings, oppressions, and wars among others. Higher education is essential to create the intellectual capacity to produce and use knowledge and lifelong learning required by people to update their knowledge and skills (World Bank, 2003; Delors 1996). Higher education is considered the biggest challenge given the demands of today's global society with the characteristics of the twenty-first century along with globalization as an emerging concept, and the efficiency and the transition from a technological society to a knowledge society. (Palomares Ruiz, 2004; Bozu \& Canto, 2009). 
According to UNESCO, cultural diversity is a source of creativity and innovation and its recognition fosters social inclusion and participation. The term wise knowledge refers to the methodical processes of production of new knowledge, traditionally known as scientific research, but there's also another knowledge where the method is called style, and also generates new knowledge. That's the case of art, another type of knowledge. Both science and the art have their respective technical and technological manifestations (Álvarez, 2009).

Wise knowledge makes its own discourse that's usually communicated in a scientific or aesthetic language. They are called ancestral and traditional knowledge and traditions to all the knowledge that owns the indigenous peoples and communities, and that have been transmitted from generation to generation for centuries (Palomares Ruiz, 2014).

The university plans a determinant role in the integral formation of individuals, that's why they have the obligation to include sustainability on their curricula so that future professionals develop their work from a sustainable perspective leading them to act responsibly and commit to their most direct environment (Azcárate, Navarrete, \& García, 2012). The university sustainability proceeds are not easy and they have the potential to transform the educative model. The challenge is to find out the best way to be affective, a path that every single university should build. Given the current context of European convergence, which advocates competency-based training, it seems like a good time to start the journey (Ull, Martínez, Piñero, \& Aznar, 2010).

The applied methodology was comparative at performing an analysis between the various strategies for imparting ancestral knowledge. The conclusions reveal which methodology is the most suitable to be able to insert the knowledge in the university.

\subsection{Retrospective Evolution}

\section{Colonization of Knowledge}

The history of knowledge is marked geo-historically and it has a value and a place of origin (Castro-Gómez \& Guardiola Rivera, 2011). Knowledge is not abstract and unfocused, it's quite the opposite (Lander, 2013). The missionaries had noticed that Aztecs or Incas had no writing, therefore, they had no knowledge in the sense that the Renaissance University conceived the knowledge (Lander, 2011). When it was time for the french and english missonaries, en XIX century, the observations were similar. Only this time the knowledge was measured on the basis of the Kantiana-Humboldtian University and not Renaissance anymore (Shari'ati, 2009; Walsh, 2011; Schiwy \& Ennis, 2012).

Therefore, human knowledge that does not occur in a region of the globe from Greece to France or to the north of the Mediterranean. Knowledge is produced in many places but, for example, knowledge produced in Africa, Asia or Latin America may not be sustainable (Dussel, 2014). This power relation marked by colonial differences and colonial statutes of power that's to say, the discourse that justifies the colonial difference is the one that reveals knowledge, it is organized through power centers and subaltern regions (Ramón, 2012). The trap is that the discourse of modernity has created the illusion that knowledge is de-incorporated and de-localized and that it is necessary, from all regions of the planet, to rise to the epistemology of modernity (Andrade Palma, 2015).

In this way, research is worthy whether it's produced in the right, the left or the center of the world. There are three great narratives, macro-narratives that are characterized as the histories of knowledge that are located from Greece to France to the north of the Mediterranean (Marín Díaz, 2017). The Christian macro-story generated the liberal macro-story and this generated the macro-macro Marxist account (Sosa Elízaga, 2011). As it's known, the secularization of knowledge apparently opposed and distanced itself from Christianity (Fachin, 2013). However, in a complementary gesture, Christianity was kept close since the Christian religion was necessary to the philosophers of illustration to ensure that all other religions were inferior to Christianity (Caldas \& Rodríguez, 2014).

Likewise, we know that secularization developed liberalism then liberalism generated its counterpart, Marxism (Hessen, 2016). So that Christianity, liberalism and Marxism with their corresponding "neo's" are not two sides of the same coin, but three sides of one side of the coin (Hume, 2013). On the other side of the coin is colonialism and finally, colonialism opens the doors of all of those fields knowledge that were marginalized in the name of Christianity, liberalism and Marxism. (Locke, 2013).

\section{Ancestral Knowledge}

Ancestral knowledge is part of the heritage of a country and its value is not limited to original communities, but that knowledge is an important resource for all mankind as it enriches mutual knowledge through dialogue and 
allows the preservation of the broad spectrum of cultural diversity in a given territory (Bozú \& Canto, 2009). According to UNESCO, cultural diversity is a source of creativity and innovation and its recognition fosters social inclusion and participation.

Therefore, ancestral knowledge must be protected and promoted, recognized and consolidated for the benefit of all mankind by the current generations and future ones (Cerda-Gutiérrez, 2016). It also ensures that cultural diversity broadens the possibilities of choice offered to all and is a source of development, understood not only in terms of economic growth, but also as a means of access to an intellectual, effective, moral existence and satisfactory spirituality (Delors, 2000). The international organism gives the necessary recognition to all cultural expressions that exist and that have existed on the planet (Gomez, 2014). In this ambit, the struggle in Ecuador has shaped the framework of the historical project of Sumak Kawsay. It encourages the the rescue, preservation and divulgation of ancient knowledge (Gonzales, Galindo,\& Gold, 2014).

It's denominated knowledge and ancestral knowing and traditions to all of those knowledge that ancient peoples own, and that have been transmitted from generation to generation by centuries. (Palomares Ruiz, 2014) This knowledge, knowing and practices had been conserved through long time mainly by using oral tradition from original peoples and also by practices and customs that have been transmitted from fathers to children in the framework in the context of the dynamics of community coexistence that characterize our indigenous peoples (Jaramillo, 2005, pág. 77).

It is not easy that a Half-Blood world tries to understand what the ancestral knowledge is really about because we should first carry out an exercise in "mental decolonization", so to speak (Chevellard, 2011). We should first understand that ancestral knowledge is the expression of a deep and complex worldview that is far from the conception of the Western world. We should know that the understanding of this knowledge cannot be given fully through a process of description, analysis, and categorization because the true understanding of ancestral knowledge arises from the experience of that worldview in which intuition and feeling intertwine with thought to generate knowledge of the world (González Agudelo \& Díaz Hernández, 2008).

Having pointed this out, and without being able to detach completely from the need to describe and categorize, it could be said that ancestral knowledge encompasses a wide variety of aspects of knowledge and technique ranging from language to gastronomy, from mathematics to crafts, passing through medicine, construction, forestry, environmental conservation techniques and microclimates, production and food, agriculture and irrigation, transport and communication, etc. (González Acosta, 2015, p.15)

Each town has its own thoughts, practices and customs that configure out the particularity of its various identities (Agosto, 2014). We can see this reflected in the difference between a craft of wild seeds of the Cofan, for example, and the well-known woven handicrafts of the Otavalo that belongs to the Kichwa nationality. It's also reflected in the difference between gastronomy, music and dance of the Amazonian Shuar people and gastronomy, dance and music of other nationalities and peoples of the Sierra or the Coast (Secretaría Nacional de Planificación y Desarrollo, 2014). In spite of these differences, there are common elements, points of encounter that are central axes within their worldviews twinned their ways of conceiving, interpreting and relating to the world.

Spirituality seems to stand out as the essential part that shapes collective identity from indigenous peoples determining its harmonic link with the Pacha Mama with the mother earth (Quintana, 2012). These are the central axes of ancestral knowledge, perhaps, the ones which should wake up more interest not only in the half-blood population, but worldwide given that they constitute elements that could give answers to some of the global needs of the present time.

Production and consumption models respectful with nature, intuitive approximation and sensitive to reality are wise enough to understand that they are a part of something much bigger than oneself, these are all components of an ancestral wisdom that has already started to call the attention to the world. In front of the actual ecological crisis as a product of the model of development at the global level, it could assume an important role in the construction of new models which permit a harmonic relation with the beings that conform to the environment and sustain our existence (Castro, 2011; CONAIE, 1989; Tarapues \& Rico, 2012).

\section{Inter-culturalism}

To sum up, the concept of inter-culturalism is defined from the perspective of indigenous social and intellectual movements,and accounts for the importance of geopolitics of knowledge (Quijano, 2016). That is, to take seriously that knowledge is not one and universal for whoever wants to gain it but is marked and marked by the colonial 
difference (Césaire, 2016). In this sense, the authors agree that inter-culturalism is thus defined as a way of overcoming internal colonialism, having the opportunity to form citizens aware of the differences and able to work together in the development of the country and in the construction of a fair society that is equitable, egalitarian and plural.

Less than two decades ago, South America began officially recognizing its ethnic and cultural diversity (Tubino, 2015). A historical diversity rooted in policies of extermination, enslavement, dehumanization, inferiority and also in the supposed overcoming of the indigenous and black. In this regard, (Trigo, 2008) indicates that this latter part of the mestization and, in countries like Brazil, Dominican Republic and the Colombian and Venezuelan Caribbean, the so-called racial democracy. In this way, there is a growing need to promote positive relationships between different cultural groups to confront discrimination, racism, and exclusion.

It is important to emphasize that inter-cultural as an epistemic, ethical and political project from the indigenous perspective is a unique manifestation of what is happening in other parts of the world (Walsh, García, \& Mignolo, 2016). On the other hand, it is a good example of the epistemic potential of border epistemology (Mignolo, 2013). An epistemology that works at the limit of indigenous knowledge subordinated by the colonialism of power (Maldonado, 2017). They are also marginalized by the colonial difference and Western knowledge translated into the indigenous perspective of knowledge and their political needs and ethical conception (Walsh, 2014).

Ecuador shares several ethnic groups and nationalities that share typical characteristics. There are usually a variety of manifestations found in myths, rites, games, legends, dances, food, costumes, etc. Collective expressions that reaffirm the cultural richness of our country (Jácome, 2013). In spite of everything, our country is great in different aspects: its culture: it has a great variety of ethnic groups settled in the Costa, Sierra and Amazonía of the country, and they maintain their customs and traditions from a long time (Diario El Tiempo, 2015).

The Republic of Ecuador has a significant percentage of the indigenous population estimated to be between $35 \%$ and $40 \%$ of the national population, grouped into 14 nationalities and 18 ethnic groups (SIDENPE, 2017). The Ecuadorian Constitution of 1998 was a significant step to address the indigenous issue by consecrating ethnic pluralism (Constitution of the Republic of Ecuador, 2008). Ecuador proclaims its will to consolidate the unity of the Ecuadorian nation in recognizing the diversity of its regions, peoples, ethnicities and cultures, defining Ecuador as a unitary, democratic, multicultural and multiethnic state (CODEMPE, 2017).

Currently 14 nationalities and 18 ethnic groups are recognized, these are:

Table 1: Ethnic Groups Source: (CONAIE, 2017) Made by: Researchers

\begin{tabular}{|c|c|c|}
\hline ETHNICS OF THE COST & $\begin{array}{c}\text { ETHNICS OF THE Mountain } \\
\text { Rage }\end{array}$ & ETHNICS OF THE AMAZON \\
\hline $\begin{array}{l}\text { - Awá } \\
\text { - Chachis } \\
\text { - Épera } \\
\text { - NegrosAfro ecuatorianos } \\
\text { - de Esmeraldas } \\
\text { - Chontubio } \\
\text { - Tsachila }\end{array}$ & $\begin{array}{ll}\text { - } & \text { Saraguro } \\
\text { - } & \text { Natabuela } \\
\text { - } & \text { Quilotoa } \\
\text { - } & \text { Quisapinchas } \\
\text { - } & \text { Salasacas } \\
\text { - } & \text { Chibuleos } \\
\text { - } & \text { Quituris Cara } \\
\text { - } & \text { Panzaleo } \\
\text { - } & \text { Otavalos } \\
\end{array}$ & $\begin{array}{ll}\text { - } & \text { Shuar } \\
\text { - } & \text { Achuar } \\
\text { - } & \text { Huaorani } \\
\text { - } & \text { Siona } \\
\text { - } & \text { Secoya } \\
\text { - } & \text { Zápara } \\
\text { - } & \text { Shiwiar } \\
\text { - } & \text { Cofán }\end{array}$ \\
\hline
\end{tabular}

Towns

The Salasaka

Approximately 12,000 inhabitants organized in about 24 communities. The organizational base is the commune (Loyola \& Surita, 2013). The highest authority is the Assembly and then the Cabildo. Being mayor gives status in the community. Work for the community is done in minga and decisions are taken democratically in the assemblies. The Salasaka are a people with an economy in transition, from a subsistence economy to a market economy. Its form of economic reproduction is differentiated by ecological floor, as follows (Valenzuela, 2013).

Crops in this area are corn, wheat, barley, beans, potatoes, cabbage, lettuce, beet, cauliflower, apple, pear, peach and capuli. They sell cakes, vegetables, capulí to complement their food and clothes. The most common animals 
are sheep and cattle. Milk production is minimal; it's given to the mestizos of the area. Good irrigation yields good quality pastures and excellent alfalfa crops oriented for the provincial market (González Terreros, 2015, pp. 7595).

They make tapestries using their own weaving techniques and traditional designs of the area. For a part of the population, this activity constitutes the main occupation oriented to the national and international market. There are some artisans who have turned their workshops into micro enterprises (Sánchez Parga, 2010). On the other hand, women, in addition to their housework, feed cattle and smaller animals such as guinea pigs and rabbits. It is important to say that a part of the Sangay National Park is located in spaces of the territoriality of the Salasaka people and in its interior are communities (La Hora, 2016).

\section{The Chibuleo}

The town Chibuleo is located in the central mountain range to the south-west of the province of Tungurahua in the canton Ambato, parish Juan Benigno Vela, $18 \mathrm{~km}$ from the city of Ambato, via Guaranda. They are bilingual, their mother tongue is Kichwa and Spanish as a second language. It is estimated that the population is approximately 12,000 inhabitants and are organized in 7 communities: San Francisco, San Luis, San Alfonso, San Pedro, Chacapungo, San Miguel and Pataló Alto. We must note that part of the territories of this town are in the Chimborazo Faunist Reserve (Campion M., 2015, pp. 243-262).

The political structure of the Chibuleo people is composed of the Community Assembly, as the highest authority, then the People's Government council, the Cabildo Comunitario, the Coordination Council, and finally the associations and cooperatives directives. All decisions and resolutions in community law are taken democratically in ordinary or extraordinary assemblies called through the Community Councils. In this Town, it is organized in the Indigenous Movement of Tungurahua, MIT (Pinos Montenegro, 2016, pp. 31-43)

The Chibuleo people, whose productive axis is the agricultural activity, takes advantage of its geographical location to plant a variety of products at the same time as they are dedicated to livestock. With regard to agriculture, they sow in small plots called blocks: potatoes, mellocos, barley, vegetables and maize, production that is destined mostly to own consumption (Nieves Loja, 2015). In relation to livestock, they are dedicated to the breeding of cattle and horses and to a lesser extent the raising of domestic animals such as lambs, pigs, chickens, guinea pigs, rabbits. Livestock activities are oriented for individual consumption and to the provincial market (Trujillo, 2012, pp. 304-314).

The Chibuelos make handicrafts such as embroidered blouses, shigras, and rebozos of white color with bands of two colors, ponchos and on a smaller scale, ceramic. Production is directed to self-consumption and the provincial market, national and even international. They maintain their ancestral celebrations combining the traditional with the religious, music, ethnic dance, dancers and the use of own ancestral instruments. Knowledge in this village is transmitted orally (Bastidas Jiménez, 2015, pp. 180-189).

Inter-culturalism seeks to develop an interaction between culturally different people, knowledge and practices. An interaction that is social, economic and political where the power of institutional conditions limit the possibility that the "other" can be considered as subject with identity, difference and agency the capacity to act (Salomon, 2013). Inter-culturalism, during the course of time, has been strengthened to overcome this rejection that is necessarily a prolonged work of education. In the interaction between individuals and groups with different cultural identities, ideas and actions of one person or cultural group are not allowed to stand above each other so that people could become more interested in this subject (Fuenzalida, 2009).

It is important to clarify that inter-culturalism refers not only to the interaction that occurs at the geographical level, but also to take into account situations in which differences occur. In educational institutions, there are different ways in which the institution is strengthened by the practice of values, traditions, which each and every one of the managers manage, contributing and promoting values so as to strengthen work and positivity (Suárez Rosas \& Barrios Osuna, 2006). The pedagogical methodology to be used in the curriculum will be based on the theories of learning of the Technical University of Ambato that is the partner constructivism, and connectivity. Each paradigm has its processes, activities and methods of action.

\section{The National Plan for Good Living and Inter-culturalism.}

The Zonal Agenda for Good Living (2013) mentions that "multi-culturalism and intercultural bilingual education in indigenous cultures have been denied meaning and validity in the universal context, this is because the idea of historical progress is considered inherent only to the Western culture" (p.11). However, it is not a question of ignoring the scientific, technological, economic and political progress of Western culture since in intercultural relations there must be a balance so that no culture becomes an instrument of hegemony and repression (Almeida, 2008). These affirmations were consolidated with the approval of the Constitution (2008), since Article 257 gives 
them the legal framework to be constituted as indigenous or Afro-Ecuadorian territorial districts that may exercise the powers of a Decentralized Autonomous Government.

Article 380 also states that one of the responsibilities of the State will be to ensure, through permanent policies, the set of values and manifestations that shape the plurinational, multicultural and multiethnic identity of Ecuador. In this context, culture is now indigenous people's proof of belonging, the verification of identity and the means of self-knowledge. This positioning before their own culture has forced them to take responsibility for the direction of it. The active participation of organizations has begun by making decisions in bilingual education, in the application of appropriate technologies, in the conscious support of the transition from oral to written and literary languages (Almeida, 2008).

Speaking of Socio-Constructivist learning, Ausubel (1968) states that "There will only be meaningful learning when what is being learned is able to relate in a substantive rather than arbitrary way with what the learner already knows, that is, with relevant aspects and Pre-existing cognitive structure "(p.13). It considers the students not as beings without knowledge, without light, but from the previous knowledge that they possess of their school experiences and of the daily life, they manage to construct new and significant knowledge, being they the main actors of their own learning. Accordingly, Robinson (1969) states that "Ancestral, traditional and popular knowledge and technologies will be integral axes of public management and will have an intercultural approach to their practices for the exercise of multi-national status" (p.5). This is similar to those who depend on the joint participation of the people possessing the ancestral knowledge and succeed in eradicating discrimination and promoting equality, inclusion and gender equality.

The Technical University of Ambato and the Career of Psycho-pedagogy will base its methodology on four axes of gender equality, of peoples, nationalities and inter-culturalism, axis of equality in the disability, axis of environment and finally the axis of gender equality, established by the National Secretariat for Higher Education, Science and Technology and Innovation and UNESCO (2013), in the document Building Equality in Higher Education, Fundamentals and Guidelines to mainstream the axes of equality and environment. It is necessary for higher education to construct learning scenarios that allow the development of gender and intercultural approaches that allow the exercise of a democratic, inclusive and diverse education.

This allows access to all the services offered by members of the university community, especially to vulnerable or socially or culturally vulnerable population groups. This will be at the same time that it carries out activities in and out of the campus with various activities linked to the community (Naranjo, 2015). It will also diligently emphasize the admission to a person with disabilities, special abilities, catastrophic illnesses, single parents or students, who for their admission must show them. It will also guarantee the permanence of students with low resources, special abilities, economic level, ethnicity, etc., in parallel with the laws and regulations in force (Campion, 2014).

\section{National Curriculum Reform}

When we speak of a global world, we emphasize the interconnection that exists today among the most remote parts of the globe thanks to modern media such as cell phones, television and the Internet, but we also allude to the fact that the whole world is making a single market in which financial capital is freely displaced and economic actors, each against all, are faced with generalized, globalized competition (Gasché, 2005, pp. 177-200).

The last curricular reform in the University, initiated in 1998, has promulgated several agreements oriented to the implementation of processes that deal with approaches, principles, characteristics and guidelines in correspondence with the PEI (1996-2010) and with the Development Plan 1996) to harmonize the academic actions that the institution has within its social function (Forero, 2008). Some provisions contemplate the need to evaluate the development of the reform, primarily pointing to aspects of the administrative nature of the curriculum but they leave out the components of vital importance for the academic future of the University (GÓMEZ, 2003; López, 1989 \& Universidad de Caldas, 1998).

Accordingly, Magendzo (1991) points out that the Curricular Reform proposals have been, with the best intention, fruit of the analyses carried out by expert groups and other gummies who have worried about the subject but have not developed in a process that could well be Research-Action for example: the proposals of Carr and Kemmis (1988), Mckernan (1999), Forero (1983) and Quintero (2001) in their idea of reflexive spiral in action to elaborate and To evaluate a proposal of curricular intervention that includes theories, models, approaches and finally specific designs of research development of the curriculum (Torres, 2004).

We have been attending a Curricular Reform implemented with the inverted spiral scheme, that is, instead of being teachers and students who study, analyze and discuss proposals, calculating their scope, limitations, costs and effects, it was a group of experts that decided and led management bodies to produce standards that are only being debated in the so-called university-based communities (Vera-Noriega, 2007). The best example of legitimacy must 
go far beyond legality: wide and deliberate participation, whether it is leisurely and meticulous, of each and every one of the actors in the process so that the final result is an approximation to the consensus and an incorporationAssimilation-respect for the created norm (Schmelkes, 2004).

In this way, curricular design in every university career starts from the fact that every community has a history, a social history, and that the social genesis of every community is always pluri traditional; in the very heart of its heritage shares many elements with other cultures. As demonstrated by the cosmovision (non-fragmented original knowledge that responds to a holistic purpose but does not have a history of institutionalization) of several peoples and cultures of the Mexican southeast and that is maintained through orality. For example, the myth of origin that depends on the culture is changing but elements are shared through them (Gay, 2004, pp. 30-49).

The lack of continuous monitoring and control of academic activities allowed for the indiscriminate proliferation of undergraduate degrees and postgraduate programs in a large number of HEIs in Ecuador that responded more to clients' demands and not to social need (Rojas, 2011). Thus, it seems that the non-fulfillment of their social responsibility was the trigger that caused the questioning of university work by various social sectors and that somehow justified the intervention of the Constituent Assembly and the National Assembly when they approved the Constitution of the Republic And the Organic Law of Higher Education LOES respectively, showing that for the Ecuadorian case the University Reform does not originate from its sine but, rather, arises from the social claim and the governmental concern (CONESUP, 2007). The transition period, which initially lasts five years, forces HEIs to overcome the process of evaluation and accreditation under penalty of being outside the System (LOES, 2010).

In this way, higher education happens to obtain curricular components, units of curricular analysis and levels that solve a problem for each semester. In addition, an opening is given to directly start the experience through the pre professional practices. Finally, the integrating knowledge project merges the transversal nature of the subjects through the integrative chair in order to obtain qualitative results that the students can support at the end of each level (Consejo de Educación Superior, 2014).

The diversification of the new curriculum of higher education proposes the integration of the knowledge and cultures of indigenous peoples and nationalities. Through inter-culturalism, we must answer the questions: what are the pedagogical methodologies of the curriculum that will achieve the incorporation of the dialogue of ancestral, every day and traditional knowledge of inclusion and diversity? What are the theoretical, methodological and attitudinal skills and skills that the curriculum will contemplate in order to achieve the incorporation of the dialogue of ancestral, daily and traditional knowledge of inclusion, diversity and gender approach? The construction of the new intercultural curriculum will allow the creation of an intercultural subject in its relations of communication, production and consumption of perceptions, knowledge, identity, transcendence, language development, thinking, socio-cultural interaction, ancestral knowledge and Cultural "(Larrea, 2015, p.24).

\section{Methodology.}

The new Ecuadorian curriculum allows integrating the ancestral knowledge. In order to achieve intercultural incorporation, it is necessary to establish methodologies that allow the adequate integration of knowledge. In the new curricular designs, methodologies are proposed, however, it is not known which ones are the right ones to be able to incorporate them.

Educational methodologies are proposed, such as:

- Tutorials.

- Evaluation.

- Individual work

- Conferences.

- Study of cases.

- Proactive Tutoring.

- Team work.

The research is carried out with a sample of 482 students corresponding to the Career of Psychopedagogy and Educational Psychology of the Technical University of Ambato aged between 19 and 25 years. 
The techniques were applied to differentiated groups applying the different methodologies proposed in the curriculum to determine which one is suitable for implementing in classrooms:

For the students of the career of educational psychology, the following methodologies were applied: tutorials, evaluation, individual works and conferences, while for the psychopedagogy career methodologies were applied: case study, problem solving, proactive tutoring and cooperative work. It should be noted in both samples that the principles of "practicum" and "action research" were used to achieve the inclusion of ancestral knowledge.

The application of observational fact sheets, which contain parameters of knowledge: education, languages and science, as an essential device for the ecology of knowledge and bio-knowledge as a crucial point of the future of knowledge. These two parameters of of knowledge were put into play through: patrimonialism, education and science, biodiversity, territoriality and governance (Crespo \& Vila, 2012). The observational form was applied to the two groups to know the degree of knowledge reached according to the application of the different methodologies. The degree of achievement was defined as 1 to 5, where q is not attained and 5 are fully achieved. Observational records were used for 5 days to obtain their average.

\section{Results.}

We measure the knowledge gained in patrimonialism, education and science, biodiversity, territoriality and governance through the observation tab:

\begin{tabular}{|l|c|c|c|c|c|}
\hline Applied methodologies & Patrimoniality & Education and Science & Biodiversity & Territoriality & Governance \\
\hline Tutorials & 3,3 & 2,3 & 3,4 & 2,1 & 3,4 \\
\hline Evaluation & 2,4 & 1,2 & 2,5 & 3,3 & 2,2 \\
\hline Individual works & 3,2 & 2,3 & 4,5 & 3,2 & 2,1 \\
\hline Conferences & 3,4 & 2,3 & 3,5 & 3,6 & 3,1 \\
\hline Study of cases & 4,1 & 4,2 & 3,9 & 4,3 & 4,1 \\
\hline Proactive Tutoring & 4,6 & 4,6 & 4,4 & 4,5 & 4,8 \\
\hline Team work & 4,5 & 4,8 & 4,8 & 4,6 & 4,2 \\
\hline
\end{tabular}

Table 2. Methodologies applied vs methodologies.

Prepared by: Researchers

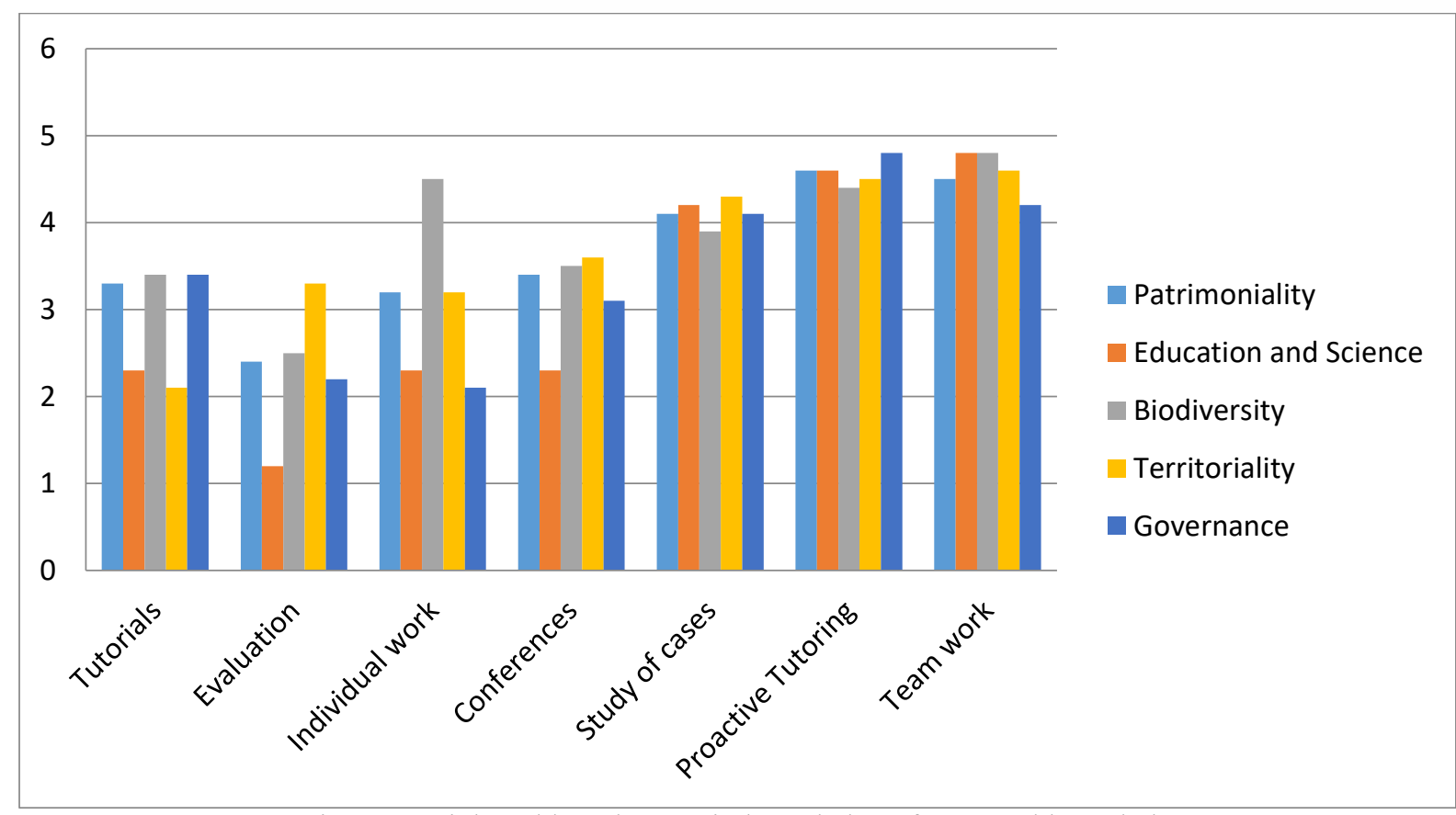

Figure 1. High and low degrees in knowledge of ancestral knowledge

Prepared by: Researchers 
The highest and lowest degrees obtained for patrimonialism, education and science, biodiversity, territoriality and governance, are:

Table 3. Means of applied methodologies. Prepared by: Researchers

\begin{tabular}{|l|c|}
\hline \multicolumn{1}{|c|}{$\begin{array}{c}\text { Applied } \\
\text { methodologies }\end{array}$} & Measure \\
\hline Tutorials & 2,9 \\
\hline Evaluation & 2,32 \\
\hline Individual works & 3,06 \\
\hline Conferences & 3,18 \\
\hline Study of cases & 4,12 \\
\hline Proactive Tutoring & 4,58 \\
\hline Team work & 4,58 \\
\hline
\end{tabular}

In that way, we can determine that the methodologies that serve most effectively for the capture of ancestral knowledge are: case study, proactive tutoring and cooperative work.

The results were analyzed: the group that received the knowledge with the methodologies: tutorials, evaluation, individual works and conferences; versus the group that received the knowledge with the methodologies: case study, proactive tutoring and cooperative work. We apply the Pearson correlation coefficient to the means:

Table 3. Pearson's correlation Prepared by: Researchers.

\begin{tabular}{|l|c|}
\hline Pearson correlation $(\mathbf{r})$. & $-0,72829874$ \\
\hline Determination $(\mathbf{r} * \mathbf{r})$ & 0,53041906 \\
\hline
\end{tabular}

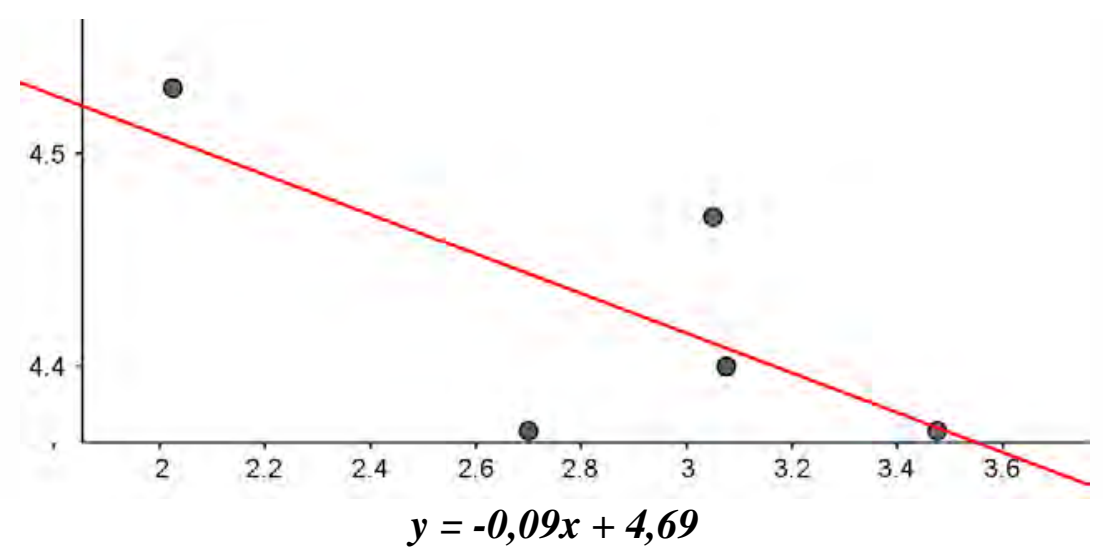

Figure 2. Dispersion diagram Prepared by: Researchers.

There is a correlation between the knowledge of ancestral knowledge between the two groups. It is a negative but not perfect correlation; this means that the difference between the methodologies applied to the two groups is too diverse to capture the ancestral knowledge.

The value $r \neq 0$ : $r>0$; Therefore, the methodologies used by the teacher has a correlational influence on the student's learning in order to capture the knowledge of the ancestral knowledge and in accordance with what is established in the Decision Rule, it can be affirmed that the methodologies: case studies, Proactive tutoring and cooperative work, are the ideal ones to be able to impart the knowledge of the ancestral knowledge. It should be noted that in a macro way practice and research should be considered. 


\section{Conclusions}

It is difficult to the half-caste population to understand the knowledge and ancient practices of the indigenous peoples, because it is not possible to speak about inter-culturalism.

There must be constructed scenes of learning that they facilitate interculturalidad across the currícula and allow the exercise of a democratic education, enclosing and diverse, guaranteeing a community conviviality by means of the practice of positive relations between several ethnic groups.

It is important to identify which are the most suitable methodologies that allow to integrate in an effective way the knowledge raised in the curriculum developments to obtain an education of general type where they all and all have the same opportunities without any type of discrimination across the interaction between the different cultures and the cooperative learning, obtaining a mutual enrichment that ensues from the exchange, the reciprocity and the interdependence.

It is possible to affirm that the methodologies: case study, proactive tutoring and cooperative work, are the ideal ones to be able to impart the knowledge of the ancestral knowledge. The tutoring starts from the conception of the subject to guarantee its cognitive autonomy; That is to say, that the process of practicum with its Principles, of understanding the teaching practice as a space that generates learning, the profile of tutor, non-segmented practice, observation reflection and the process itself of the investigation through the monitoring and control . These principles are applicable in a better way if we apply the methodologies applied.

\section{References}

1. Agosto, P. (2014). Saberes ancestrales y biodiversidad. Destrucción, negación y disputa. Centro de Investigación y Formación de los Movimientos Sociales Latinoamericanos (CIFMSL). Buenos Aires: Consejo Latinoamericano de Ciencias Sociales.

2. Almeida, A. (2008). La Pluriculturalidad. Quito, Ecuador: Ruíz.

3. Álvarez, C. (2009). Hacia una escuela de excelencia, $2^{a}$ ed. La Habana: Academia.

4. Andrade Palma, M. (Viernes de Marzo de 2015). Colonización del conocimiento. El Diario Manabita de libre pensamineto.

5. Ausubel, D. P. (1968). Educational Psychology: A Cognitive View. New York: Holt, Rinehart \& Winston.

6. Azcárate, P., Navarrete, A., \& García, E. (2012). APROXIMACIÓN AL NIVEL DE INCLUSIÓN DE LA SOSTENIBILIDAD EN LOS CURRICULA UNIVERSITARIOS. Profesorado. Revista de Currículum y Formación de Profesorado, vol. 16, núm. 2, 105-119.

7. Bastidas Jiménez, M. (2015). Educación Intercultural Bilingüe en el Ecuador: Un estudio de la demanda social. ALTERIDAD. Revista de Educación, vol. 10, núm. 2, julio-diciembre, 2015, 180-189.

8. Bozú, Z., \& Canto, P. (2009). El profesorado universitario en la sociedad del conocimiento: competencias profesionales docentes. Revista de formación e innovación educativa universitaria, 2, 2, 87-97.

9. Caldas, A., \& Rodríguez, C. (2014). La regulaci n jur dica del conocimiento tradicional : la conquista de los saberes. Bogotá: ILSA.

10. Campion, M. (2014). La organización indígena transfronteriza en los márgenes del Ecuador. Perspectivas desde la Sierra, Costa y Amazonía. Tesis Doctoral. Manuscrito sin publicar. En prensa.

11. Campion, M. (2015). Entre la memoria histórica y el atentado: las relaciones transfronterizas de los indígenas. Revista Científica "General José María Córdova", vol. 13, núm. 16, julio-diciembre, 2015, 243-262.

12. Castro, J. (2011). Elementos de reflexión para una agenda ambiental en la frontera entre Colombia y Ecuador. Rostros y Rastros, 35-44.

13. Castro-Gómez, S., \& Guardiola Rivera, O. (2011). El Plan Colombia, o de cómo una historia local se convierte en diseño global. Nueva Sociedad, 175.

14. Cerda-Gutiérrez, H. (2016). Formación investigativa en la educación superior colombiana. Bogotá: EDUCC.

15. Césaire, A. (2016). Discurso sobre el colonialismo. Madrid: Akal.

16. Chevellard. (2011). La transposición didáctica. Del saber sabio al saber enseñado. Buenos Aires: Aique.

17. CODEMPE. (2017). Pueblos y Nacionalidades del Ecuador. Quito: Ruíz.

18. CONAIE. (1989). Las nacionalidades indigenas en el Ecuador: Nuestro proceso organizativo. Quito: Ediciones Abya-Yala.

19. CONAIE. (2017). Nacionalidades y Grupos étnicos del Ecuador. Quito, Ecuador.

20. CONESUP. (2007). Reglamento de doctorados, Ecuador. Quito.

21. Consejo de Educación Superior. (2014). Reglamento de Régimen Académico . Quito: CES.

22. Constitución de la República del Ecuador. (2008). Educación. En C. d. Ecuador, Constitución de la República del Ecuador (pág. 27). Alfaro, Montecristi: Ruíz. 
23. Crespo, J. M., \& Vila, D. (2012). Saberes y conocimeintos ancestrales, tradiciones populares. Stream 5: Comunidades, 48-96.

24. Delors, J. (2000). La educación encierra un tesoro. Madrid: Santillna. UNESCO.

25. Diario El Tiempo. (Lunes de Noviembre de 2015). El Ecuador, reconoce la existencia de los diferentes pueblos y nacionalidades, de acuerdo a la Constitución de 2008. Diario El Tiempo, pág. 2.

26. Dussel, E. (2014). Historia de la filosofía y filosofía de la liberación. Bogotá: Nueva América.

27. Fachin, L. E. (2013). La Conquista de los Saberes. Bogotá: ILSA.

28. Forero, F. (2008). Estructura Curricular de Programas Académicos Universitarios y su Relación con la Docencia, en Mejorar la Docencia Universitaria. Bogotá: Universidad Pedagógica Nacional.

29. Fuenzalida, F. (2009). La Agonía del Estado-Nación. Poder, Raza y Etnia en el Perú Contemporáneo. Lima: Fondo Editorial del Congreso de Perú.

30. Gasché, J. (2005). Hacia una propuesta curricular intercultural en un mundo global. Revista Interamericana de Educación de Adultos, vol. 27, núm. 1, 2005, 177-200.

31. Gay, G. (2004). Curriculum theory and multicultural education. En: James A. Banks y Cherry A. Mc. Gee Banks (editors). Handbook of research of research on multicultural education. 2 a ed. San Francisco California: Jossey, Bass.

32. Gómez, J. (2014). Lineamientos pedagógicos para una educación por competencias. En El concepto de competencia II. Una mirada interdisciplinar. Bogotá: Sociedad Colombiana de Pedagogía.

33. GÓMEZ, P. E. (2003). Construcción de un Currículo Integrado para la Universidad de Caldas. Informe final de investigación. . Manizales.: Vice-Rectoría de Investigaciones y Postgrados.

34. González Acosta, M. (2015). La emergencia de lo ancestral: una mirada sociológica. Maracaibo, Venezuela: Universidad del Zulia.

35. González Agudelo, E. M., \& Díaz Hernández, D. P. (2008). Desde el currículo hasta la didáctica o sobre la circulación de los saberes y sus controles en la universidad: un ejemplo en la enseñanza de la Medicina. Medellín, Colombia: Universidad de Antioquia.

36. González Terreros, M. I. (2015). Las escuelas clandestinas en Ecuador. Raíces de la educación indígena intercultural. Revista Colombiana de Educación, núm. 69, 75-95.

37. González, J., Galindo, N., Galindo, J. L., \& Gold, M. (2014). Los paradigmas de la calidad educativa. De la autoevaluación a la acreditación. México: Unión de Universidades de América Latina.

38. Hessen, J. (2016). Teoría del Conocimiento. Lozada.

39. Hewitt Ramírez, N., \& Barrero Rivera, F. (2011). La Integración de los Saberes: Una propuesta curricular para la formación en investigación en la educación superior. Bogotá, Colombia: Universidad de San Buenaventura.

40. Hume, D. (2013). Conocimineto. Prisse Hall.

41. Jácome, S. (2013). Nacionalidades y Pueblos del Ecuador. Quito: Ruiz.

42. Jaramillo, H. (2005). Interacción entre el capital humano, el capital intelectual y el capital social: una aproximación a la medición de recursos humanos en ciencia y tecnología. México: Trillas.

43. La Hora. (Miércoles de Julio de 2016). Diversidad de nacionalidades y pueblos indígenas en Ecuador. Diario La Hora, pág. 4.

44. Lander, E. (2011). Los derechos de propiedad intelectual en la geopolítica del saber de la sociedad global del conocimiento. Quito: Universidad Andina Simón Bolívar.

45. Lander, E. (2013). La colonialidad del saber. Eurocentrismo y Ciencias Sociales. La Paz: Hisbol.

46. Larrea, E. (2015). El Curriculo de la Educación Superior desde la Complejidad Sistémica. Quito: Consejo de Educación Superior.

47. Locke, J. (2013). El empirismo del conocimiento. México: Trillas.

48. LOES, L. O. (2010). Asamblea Nacional del Ecuador. Quito: Ruiz.

49. López, N. E. (1989). Currículo y Calidad de la Educación Superior en Colombia. Bogotá: ICFES COLCIENCIAS.

50. Loyola, G., \& Surita, A. (2013). 14 Nacionalidades \& 18 Grupos Etnicos Ecuador . Santa Cruz - Cascajo, Galapagos, Ecuador: Loyola Lodge.

51. Magendzo, A. (1991). Currículo y Cultura en América Latina. Santiago de Chile: PIIE. 2da. Edición.

52. Maldonado, N. (2017). "Sobre la colonialidad del ser: contribuciones al desarrollo de un concepto”, en El giro decolonial. Reflexiones para una diversidad epistémico más allá del capitalismo global. Bogotá: Siglo del Hombre.

53. Marín Díaz, M. A. (2017). Colonizacion y municipalizacion en la Hispania republicana. España: Universidad de Granada.

54. Mignolo, W. (2013). Historias locales/diseños globales. Colonialidad, conocimientos subalternos y pensamiento fronterizo. Madrid: Akal.

55. Naranjo, g. (2015). Políticas de acción Afirmativa de equidad de Género para la Docencia y la Gestión. Ambato: Universidad Técnica de Ambato. 
56. Nieves Loja, G. M. (2015). EL CARÁCTER RECONSTRUCTIVO DE LA JUSTICIA INDÍGENA, EN CHIMBORAZO, ECUADOR: PERSPECTIVA ÉTICA. Aufklärung. Revista de Filosofia, vol. 2, núm. 2 , octubre, 2015, 79-102.

57. Palomares Ruiz, A. (2014). Profesorado y educación para la diversidad en el siglo xxi. España: Universidad de Castilla-La Mancha.

58. Pinos Montenegro, J. (2016). IMAGINARIO CREADOR Y POBREZA. ESTUDIO ETNOGRÁFICO ENTRE INDÍGENAS KICHWAS DEL CANTÓN AMBATO, PROVINCIA DE TUNGURAHUA ECUADOR, QUE SALIERON DE POBREZA Y LOS QUE VIVEN EXTREMA POBREZA. Diálogo Andino - Revista de Historia, Geografía y Cultura Andina, núm. 51, 2016, 31-43.

59. Quijano, A. (2016). "Estado-nación y 'movimientos indígenas' en la región Andina, cuestiones abiertas”, enMovimientos sociales y gobiernos en la región andina. Resistencias y alternativas, Lo político y lo social. Revista del Observatorio Social de América Latina, CLACSO, 15-24.

60. Quintana, R. (2012). Estudio de plantas medicinales usadas en la comunidad indígena Tikuna del alto Amazonas. Macedonia: Nova 10.

61. Ramón, R. (2012). La nueva colonización de América Latina, la tecnológica y el conocimiento. Rebelión, 21.

62. Rengifo-Salgado, E., Rios-Torres, S., Fachín Malaverri, L., \& Vargas-Arana. (2017). Saberes ancestrales sobre el uso de flora y fauna en la comunidad indígena Tikuna de Cushillo Cocha, zona fronteriza PerúColombia-Brasil. Revista Peruana de Biología, vol. 24, núm. 1, 2017, 67-78.

63. Robinson, F. G. (1969). School Learning: An Introduction To Educational Psychology. New York: Holt, Rinehart \& Winston.

64. Rojas, J. E. (2011). Reforma universitaria en el Ecuador. Etapa de transición. Innovación Educativa, vol. 11, núm. 57, octubre-diciembre, 2011, , 59-67.

65. Salomon, F. (2013). SUPERMÁN ES MÁS SÚPER CUANDO SE QUITA LA MALLA. Chungara, Revista de Antropología Chilena, vol. 45, núm. 4, 2013, 515-522.

66. Sánchez Parga, J. (2010). El movimiento indígena ecuatoriano. La larga ruta de la comunidad al partido. Quito: Abya-Yala.

67. Schiwy, F., \& Ennis, M. (2012). Knowledges and the Known. Andean Perspectives on Capitalism and Epistemology. Nepantla: Views from South.

68. Schmelkes, S. (2004). Avances y retos de la educación superior indígena en México. Coordinación general de educación intercultural y bilingüe, en educación superior para los pueblos indígenas de América latina, memoria del segundo encuentro regional. México, D.F: México, CGEIB-SEP.

69. Secretaría Nacional de Planificación y Desarrollo. (2014). Plan Nacional para el Buen Vivir 2013-2017. Quito, Ecuador.

70. Shari'ati, A. (2009). On the sociology of Islam. Berkeley: California University Press.

71. SIDENPE. (2017). Nacionalidades y pueblos indigenas del Ecuador. Quito: Ruíz.

72. Sosa Elízaga, R. (2011). Pensar con cabeza propia. Educación y pensamiento crítico en América Latina. Buenos Aires: CLACSO.

73. Suárez Rosas, L., \& Barrios Osuna, I. (2006). La universidad como líder en la solución de los problemas de salud. El proyecto "Pelileo". Revista Cubana de Salud Pública, vol. 32, núm. 3.

74. Tarapues, E., \& Rico, A. (2012). Gobernabilidad y aspectos culturales en resolución de conflictos ambientales. Bogotá: Editorial Universidad del Rosario.

75. Torres, J. (2004). Globalización e Interdisciplinariedad: El Currículo Integrado. Madrid: Ediciones Morata.

76. Trigo, A. (2008). La tarea pendiente de los estudios culturales latinoamericanos en Cultura y cambio social en América Latina. Madrid: Iberoamericana/Vervuert.

77. Trujillo, J. (2012). Plurinacionalidad y Constitución. Ecuador: Abya Yala.

78. Tubino, f. (2015). "La interculturalidad crítica como proyecto ético-po co", Encuentro continental de educadores. Lima: Ibid.

79. Ull, M., Martínez, M., Piñero, A., \& Aznar, P. (2010). Análisis de la introducción de la Sostenibilidad en la Enseñanza Superior en Europa: compromisos y propuestas curriculares. evista Eureka sobre Enseañanza y Divulagación de las Ciencias.

80. UNESCO. (2013). Organización de las Naciones Unidas para la Educación, la Ciencia y la Cultura. Constitución de la Unesco.

81. Universidad de Caldas. (1998). Plan de Desarrollo. Manizales: UNIVERSIDAD DE CALDAS.

82. Valenzuela, O. (2013). La Nacionalidad Ecuatoriana. Quito: Universidad Central del Ecuador.

83. Vera-Noriega, J. Á. (2007). TEORÍA Y MÉTODO EN EL DISEÑO CURRICULAR INTERCULTURAL POR COMPETENCIAS. Hermosillo, Sonora: Centro de Investigación en Alimentación y Desarrollo, A.C.

84. Vivir, L. A. (2013). Propuestas de Desarrollo y Lineamientos 8 para el Ordenamiento Territorial en el punto 2 de Diagnostico. Quito.

85. Walsh, C. (2011). ¿Qué conocimiento(s)? Reflexiones sobre las políticas de conocimiento, el campo académico, y el movimiento indígena ecuatoriano. Quito: Boletín ICCI Rimai. 
86. Walsh, C. (2014). Construir la interculturalidad. Consideraciones críticas desde la política, la colonialidad y los movimientos indígenas y negros en el Ecuador. Interculturalidad y política. Lima: Red de apoyo de las ciencias sociales, en prensa.

87. Walsh, C., García, Á., \& Mignolo, W. (2016). “Interculturalidad y colonialidad delpoder: Un pensamiento y posicionamiento otro desde la diferencia colonial”, en Interculturalidad, descoloniza ndel Estado y del conocimiento. Buenos Aires: Signo. 